\title{
Relationship Between Religious Orientation (Internal-External) With Methods of Overcoming Stress in Students of Islamic Azad University of Abhar
}

\author{
Alireza Jafari \\ Islamic Azad University (Abhar Branch), Abhar, Iran
}

\begin{abstract}
This study explored the relationship between religious orientation (internal-external) and the ways of coping stress (problem-based and emotion-based) in the students of IAU (Islamic Azad University), Abhar Branch. Religion with internal origin is comprehensive and has well-organized principles. However, religion with external origin is a device to meet needs as relaxation, sociability, security, self-justification and job position. The research design was casual-comparative and the sample size included 250 BA (baccalaureate) and associate degree students that were chosen randomly in 1,384 students studying in different majors in IAU, Abhar Branch. Research instruments were ROS (religious orientation scale) (internal-external) and WOC (ways of coping questionnaire). After test administration, 50 students that had the lowest scores were known as internal religious-oriented and 50 students who got the highest scores were known as external religious-oriented. Then, the coping ways (problem-based and emotion-based) in the two groups were considered. $T$-test was implemented to analyze data. The findings, on the whole, approved the research hypotheses asserting that students with internal religious orientation used the problem-based coping way in a higher degree than external religious-oriented ones. Also, the external religious-oriented students used the emotion-based coping way more than the counter group. In relation to the four minor research hypotheses, there was a significant difference between the means of the two groups with internal and external religious orientation in each of the sub-scales of the emotion-based coping way (confrontation, self-control, escaping and avoidance).
\end{abstract}

Keywords: stress, internal religious orientation, external religious orientation, coping

\section{Introduction}

In this century, mental pressure and stress are one of the main fields of research in many disciplines and surveying its effects on our life is one of the widest research fields of modern age. Stress, anxiety and finding remedies are a common part of our daily life. Facing with stressful situation is not rare happening in our life. Causes like usual stressful events or disastrous events which happen in some occasions differ from one person to another.

Remedies and technique to lessen stressful events in life play a significant role in physical and mental health of people. Assessment and counter measures are just cognitional and behavioral quests on construing and fighting life obstacles (Moss \& Shefer, 1993).

Alireza Jafari, Ph.D., Department of Psychology, Islamic Azad University (Abhar Branch). 
In primary appraisal discussion, an even may be considered threatening or safe by observer. In secondary appraisal discussion, type of counter measure, which need to be taken by individual in a specific condition and also facilities and capabilities to settle them are under focus. Recognition of danger and its intensity depend on facilities the individual believes has access to, which is based on information he/she may have about environment, life experiences and personal specifics. Fresh information may affect individual's appraisal about the situation for reassessment (Azad, 1999).

A characteristic or environmental variable may act as a stress regulator under influence of individual dependency to specific countering strategy. First, it is possible to influence semantic assessment of events (threat/no threat). Second, it is possible to influence counter measures resources (as cited in Mokhtari, 2010).

Previous researches have shown that being a religious is very effective on regulating intense crisis during life. For instance, Cook and Wimerly (1983) reported that feeling religious commitment is effective on the way parents cope with devastating news about their children cancer and blood disorders (Park \& Cohen, 1990).

Recently, many researches have been conducted about correlation between religious beliefs and metal well-being (Ellison, 1994).

However, some researchers have argued about unclear and misty relation between different aspects of piousness and psychological compatibility. It seems that religious beliefs may have both negative and positive effects on mental health, and based on personal religious viewpoints, the same event leads to different consequences.

Tylor (1983) in his study, for example, on cancer patients observed that some patients construed cancer as a divine test of faith, while others considered it just as a threat (Park \& Cohen, 1990).

Allport (1963) believed that we have all we need for mental health. In this regard, he emphasized on importance of religious beliefs and mental health (Janbozorgi, 1999).

Nazar Wicklin (1990) argued that difference between internal and external religion plays the main role regarding experimental studies on religion. Allport and Ross (1967) believed that shortest path for thematic classification of religion is to say a person with external motivation utilizes his/her religious beliefs while one how is motivated internally actually live with his/her religion.

A person with internal religious beliefs finds what needed for motivation in religion. It is not possible to distinguish between character and religion of these people. This is the reason why people with external religious motivation look for other goals by walking toward religion. In other words, they step toward God while having themselves in mind (as cited in Viten, 1994).

Watson (1994) believed that religious approaches may be used as an experimental pattern for identifying relation between faith purity and characteristics and mental health.

Looking at what mentioned earlier, the main question in this research was that "Whether religious approaches of individuals are effective on how they cope with stressful situations?”.

\section{Research Methodology}

This research tries to survey and crystallize relation between religious approaches (internal-external) and coping with stress (issue-based/anxiety-based). Case study in this research is comprised of all students in IAU (Islamic Azad University), Abhar Branch in academic year of 2005-2006, including 250 BA (baccalaureate) and associate level students selected randomly. In this matter, students' information based on their field of study, gender and academic department was gathered from the university datacenter, afterward, some fields 
were selected randomly. Afterward, students were studied using Allport's religious approach scale (internal/external) and asked to answer Lazrous and Flokmen's comparative questionnaire. Subsequently, 50 students with lowest score in religious approach test were classified in external religious approach group. Afterward, researchers defined coping techniques applied by members of this group. At the end of the test, using research data resulted from $T$-test on two independent groups in SPSS (statistical package for the social sciences) software, research hypotheses where analyzed for defining religious approaches (internal-external) and coping method (issue-based/anxiety-based).

Tables 1, 2, 3 and 4 are some examples.

Table 1

Frequency and Gender Percentage in Study Group

\begin{tabular}{lcc}
\hline Gender & Statistical indexes & Percentage (\%) \\
\hline Male & Frequency & 39.6 \\
Female & 95 & 61 \\
Total & 155 & 100 \\
\hline
\end{tabular}

Table 2

Frequency and Age Percentage in Study Group

\begin{tabular}{|c|c|c|}
\hline Age (year) & Statistical indexes Frequency & Percentage (\%) \\
\hline 19 & 46 & 18.4 \\
\hline 20 & 50 & 20 \\
\hline 21 & 41 & 16.4 \\
\hline 22 & 54 & 20 \\
\hline 23 & 18 & 7.2 \\
\hline 24 & 18 & 7.2 \\
\hline 25 & 10 & 4 \\
\hline 26 & 3 & 1.2 \\
\hline 27 & 2 & 0.8 \\
\hline 28 & 3 & 1.2 \\
\hline 30 & 2 & 0.8 \\
\hline 32 & 2 & 0.8 \\
\hline 33 & 1 & 0.4 \\
\hline Total & 250 & 100 \\
\hline
\end{tabular}

Table 3

Frequency and Field of Study Percentage in Study Group

\begin{tabular}{lcc}
\hline \multicolumn{2}{c}{ Field of study } & Percentage (\%) \\
Engineering and technical indexes & Frequency & 20.8 \\
Basis sciences & 52 & 15.2 \\
Humanities & 38 & 61.2 \\
Nursing & 153 & 2.8 \\
Total & 7 & 100 \\
\hline
\end{tabular}


Table 4

Independent T-test Among Students With Internal/External Religious Approaches in Issue-Based Cope Techniques

\begin{tabular}{|c|c|c|c|c|}
\hline Field of study & Statistical indexes Number & Average & Standard deviation & Standard error \\
\hline Internal & 50 & 28.41 & 7 & 1.14 \\
\hline External & 50 & 33.86 & 8.2 & 1.14 \\
\hline
\end{tabular}

Notes. $T=3.25 ; d f=98 ; P<0.001$.

Table 5

Independent T-test Among Students With Internal/External Religious Approaches in Anxiety-Based Cope Techniques

\begin{tabular}{|c|c|c|c|c|}
\hline Field of study & Statistical indexes Number & Average & Standard deviation & Standard Error \\
\hline Internal & 50 & 31 & 7.92 & 1.1 \\
\hline External & 50 & 25.7 & 9.18 & 1.14 \\
\hline
\end{tabular}

Notes. $T=2.59 ; d f=98 ; P<0.002$.

\section{Measurement Tools}

Allport's internal-external religious approach scales, ROS (religious orientation scale), and Lazarous and Folkman's cope methods scale, WOC (ways of coping questionnaire), are the two tools for assessing religious approaches and stress cope technique relation. What follows is to give reader a brief description of each tool.

Allport's religious approach questionnaire is a 20-step scale comprising 11 items for internal and nine items for external religious approaches. According to Allport, there is correlation of -0.21 between internal and external religious approaches. In some other studies, including Figen's works, the correlation is calculated equal to -0.20, which is significantly close to Allport's calculated correlation (Donahue, 1985).

Pointing order follows Likret’s scale: 5: "Completely disagree”; 4: “Almost disagree”; 2: “Almost agree”; and 1: "Completely agree”. Generally, lower points usually gained by people with internal religious approach, while higher points won by those with external religious approach and, based on scores distribution in religious approach scale, those with points between higher and lower 30\% are selected as two main case studies.

Lazarous and Folkman's cope questionnaire (WOC) generally comprises of 66 articles, which measures six issue-based/anxiety-based cope methods. According to Lazaros, internal stability of from 0.79 to 0.66 is advised for each cope technique. Cope scales in the questionnaire are: 1: cope/facing method; 2: avoiding; 3 : self-control; 4: seeking social support; 5: responsibility; and 6: evasion/escaping

There are some other questions that may not be classified in the above six groups. Issue-based section includes four positive specifics, such as seeking social support, responsibility, finding reasonable solution and assessment, and four negative specifics, such as facing, avoiding, self-control and evasion.

\section{Findings}

Results of the study are analyzed in two sections including deductive and descriptive. In case of descriptive result analysis, frequency and gender percentage among 250 participants, among who 95 (39.6\%) are males, 155 (61\%) are females, 56 participants under 22 (24.7\%) with highest frequency and one $(0.3 \%) 33$ years old participant with lowest frequency. Among 250 participants, 52 (20.8\%) participants were in engineering and 
technical field, 38 (15.2\%) in basic sciences, 153 (61.2\%) in humanities and seven (2.8\%) in nursing.

Deductive surveys on data through independent $T$-test between averages of two groups of students with internal-external religious approaches in relation to issue-based cope technique yield 3.25 as calculated "T" which is bigger than " $T$ " value in table (2.617) with free level of 98 at 0.01 (see Table 4).

In addition, surveys on independent $T$-tests results between averages of the two groups of students with internal-external religious approaches in relation to anxiety-based cope techniques showed that calculated " $T$ " (2.59) is bigger than "T" value in table (2.617) with free level of 98 at 0.01 (see Table 5).

\section{Conclusions}

Stress, anxiety and how to cope with them are just parts of our life. We all have faced with stressful causes including usual depression to great disaster of life. Stress is one of the main reasons of incompatibilities and mental diseases. From academic viewpoint, methods applied by individuals who attain stressful cause play main role in determining physical and mental health. Some personal causes and variables may lead to lessen to a high level of stress to regulate its damaging effects. Considering these causes, individuals may cope with life stressful occasions more easily. Many researchers have shown religious beliefs which have to do with cope stressful situations. Role of religious on mental health and methods for cope with stressful situations has received attentions from many studies during last decades.

The main aim of the research is to survey religious approach's (internal-external) effects on methods for cope stressful situations (issue-based/anxiety-based). Results generally confirmed hypothesis of the study.

Regarding second hypothesis-students with external religious, approaches generally tend to used anxiety-based techniques comparing with students with internal religious approaches. Results showed that there is meaningful relation between techniques for cope stressful situation by average students with internal-external religious approaches using anxiety-based cope techniques. We can say, therefore, that students with internal religious approaches tend to apply issue-based technique for cope stressful situation more that those with external religious approaches.

\section{References}

Abbass Mokhtari. (2000). A survey on relations between religious approaches (internal/external) and tension rate (Master's thesis, Tarbiat Modaresh University).

Allport, G. W., \& Ross, J. M. (1967). Personal religious orientation and prejudice. Journal of Personality and Social Psychology, 5, 423-443.

Azad, H. (1999). An outline of psychopathology. Tahran: Besat Press.

Delavar, A. (1999). Research methodology in psychology and training sciences. Tehran: Viraiesh Press.

Donahue, M. J. (1985). Intrinsic and extrinsic religiousness: Preview and meta-analysis. Journal of Psychology and Social Psychology, 48.

Ellison, C. G. (1994); Religious involvement and subjective well being. Journal of Health and Social Behavior, 32, 80-99.

Masoud J. (1999). Surveying effectiveness of psychotherapy with/without Islamic religious approach on anxiety and tension (Doctoral dissertation, Tarbiat Modares University).

Ostovara. (1998). Tension or stress (Parirokh Dadsetan trans.). Tehran: Roshd Press.

Park, C. L., \& Cohen, L. H. (1990). Religious and nonreligious coping with the death of friend. Journal of Cognitive Therapy and Research, 17.

Shamlou, S. (1993). Mental health. Tehran: Roshd Press.

Watson, P. J. (1994). Religion and rationality: Comparative analysis of rational emotive and intrinsically religious irrationalities. Journal of Psychology and Christianity, 13(4), 373-384.

Weiten, W. (1994). Stress, coping and health in handbook of psychology. Brooks/Cole Company. 